\title{
Spectrophotometric determination of trace amount of iron in water, food, and pharmaceutical samples
}

\author{
M. M. Hossain*, M. M. H. Khan, R. S. Prattaya, M. H. Yasmin and M. Khatun
}

Jashore University of Science and Technology, Jashore-7408, Bangladesh

Received: 02 November 2021

Revised: 24 November 2021

Accepted: 01 December 2021

DOI: https://doi.org/10.3329/bjsir.v56i4.57194

\begin{abstract}
The present study aimed to determine the trace amount of iron by using highly selective and sensitive spectrophotometric reagents in water, food, and pharmaceutical samples. For this, as-triazine containing ferroin-yielding chromogens; 3-(2-pyridyl)-5,6-diphenyl-1,2,4-triazine (PDT) and 3-(2-pyridyl)-5,6-bis( $p$-methoxyphenyl)-1,2,4-triazine (PBMPT) have been synthesized. The absorptiometric characteristics of the iron(II) complexes with PDT and PBMPT such as complex formation, sensitivity determination, composition determination have also been studied. It has been observed that these highly sensitive and selective ferroin-yielding reagents act as bidentate ligands and form intensive colored tris-complexes with iron(II) ions. The application of these spectrophotometric reagents for the determination of iron in water, food, and pharmaceutical amples has been described.
\end{abstract}

Keywords: as-triazine; Spectrophotometer; Water sample; Food sample; Iron tablet

\section{Introduction}

Iron is one of the most essential inorganic elements in the biological system. Iron plays an enormous role in human health such as formation of hemoglobin, muscle function, brain function, body temperature, enhancing immunity, boosting energy and so on (Cronin et al., 2019). However, both excess and low level of iron are harmful. Iron toxicity can cause several symptoms like enlarged liver, skin pigmentation, lethargy, joint diseases, loss of body hair, amenorrhea, and impotence. Untreated hemochromatosis aggravates the risks of diabetes, liver cancer, heart disease, and arthritis (Hoffman, 2013). To contrary, iron deficiency also causes various physiological problems such as anemia, insomnia, restless leg syndrome, weaken the immunity system, increase a woman's risk of premature birth and so on (Hoffman, 2013; Clara, 2015). The recommended daily allowance for iron is $8 \mathrm{mg}$ for adult men (ages 19-50+), 18 mg for adult women (ages 19-50) and for children 10 to 15 mg (NAP, 2001). Therefore, determination of iron in our daily foods is very important to ensure a balanced amount in he human diet.
There are several methods for the determination of iron from natural samples. Among them, AAS, ICP-MS, and colorimetric methods are very common (Slavin, 1988; Jenner et al., 1990; Bosscher et al., 2001). In this study, colorimetric method has been applied because of its availability, simplicity, and less expense (Riemer et al., 2004; Patil et al., 2015; Hedayati et al., 2018; Viollier et al., 2000). This method can be used for the determination of trace level of iron when an appropriate chromogenic eagent is used.

Ferroin functional group is well-known as an iron reagent. as-triazine containing ferroin yielding chromogen is highly selective and sensitive to form colored complex with iron(II) ion (Islam and Stephen, 1993; Douglas et al., 1984; Avissaret al., 2004; Bellamand Jaganyi, 2017; Islam and Stephen, 1992, Kamal et al., 1989). 3,5,6-triazines can easily be synthesized in the laboratory from commercially available and relatively cheaper reagents (Islam and Stephen 1993; Furniss et al., 1978). 
PDT and PBMPT arevery stable organic reagents that have high stability constant with iron(II) (Islam et al., 2020). The amount of iron in iron-containing samples in terms of iron(II)-PDT and iron(II)-PBMPT complexes are determined by using UV/Vis spectrophotometer (Viollier et al., 2000; Avissar et al., 2004; Hossain et al., 2019).

In this research work, as-triazine reagents have been used to determine the iron contents of commonly used daily diet by the people of Jashore area. The people of this region fulfill their iron demand from water, foods, and in some cases from iron medicines. Whether they are consuming a balanced amount of iron by mentioning a simple method is the main purpose of our present investigation.

\section{Materials and methods}

\section{Synthesis of spectrophotometric reagents}

3,5,6-trisubstituated as-triazines; 3-(2-pyridyl)-5,6-dipheny 1-1,2, 4-triazine (PDT), and 3-(2-pyridyl)-5, 6-bis (p-methoxyphenyl)-1, 2,4-triazine (PBMPT) were synthesized according to the following reaction scheme (Islam and Stephen, 1993; Furniss et al., 1978).
The purity of the materials was confirmed by measuring melting points, elemental analysis and FT-IR spectra.

\section{Reagents}

\section{Stock iron(II) solution}

A standard iron(II) solution was prepared by dissolving the required amount of analar grade Mohr's salt in a small volume of distilled water followed by adding $5 \mathrm{ml}$ of concentrated $\mathrm{H}_{2} \mathrm{SO}_{4}$ before dilution to $1 \mathrm{~L}$ with distilled water. The solution was diluted in different working concentrations (where necessary).

\section{Organic reagent solutions}

A typical stock solution $(0.005 \mathrm{M})$ of synthesized organic reagents was prepared by dissolving the required amount of PDT and PBMPT in ethanol into two separate $250 \mathrm{ml}$ volumetric flasks respectively. In the case of PDT, 1-2 drops of concentrated $\mathrm{HCl}$ were added to dissolve the reagent. The stock solution was made diluted for the required concentration of the reagent for spectrophotometric determinations.

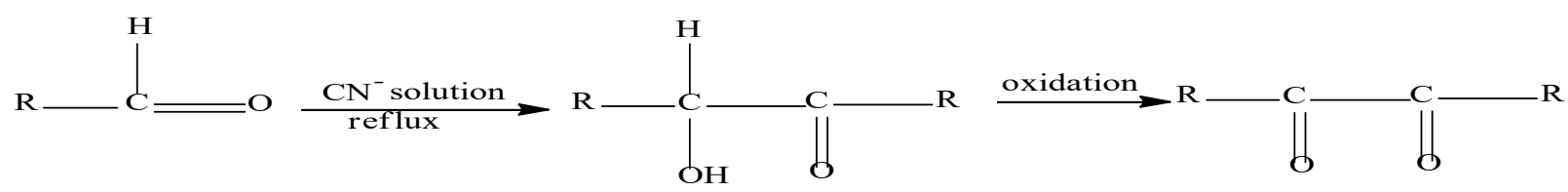<smiles>COc1ccc(C)cc1</smiles><smiles>N#Cc1ccccn1</smiles><smiles></smiles><smiles>[R][CH]Cc1ccccc1</smiles> 


\section{Buffer solution}

An acidic buffer solution ( $\mathrm{pH} 4.76$ ) was prepared by mixing of $250 \mathrm{ml} 2 \mathrm{M} \mathrm{CH} 3 \mathrm{COOH}$ solution and $250 \mathrm{ml} 2 \mathrm{M}$ $\mathrm{CH} 3 \mathrm{COONa}$ solution in a $500 \mathrm{ml}$ volumetric flask.

\section{Reducing agent solution}

A reducing agent solution of $\mathrm{NH}_{2} \mathrm{OH} . \mathrm{HCl}(10 \%(\mathrm{w} / \mathrm{v}))$ was prepared by dissolving $25.0 \mathrm{~g}$ of material in distilled water of a $250 \mathrm{ml}$ volumetric flask.

\section{Iron-free buffer solution}

The prepared buffer solution was made iron-free by the process of extraction with chloroform solvent. In a $250 \mathrm{ml}$ separatory funnel, $100 \mathrm{ml}$ buffer solution was transferred followed by adding $2 \mathrm{ml}$ of $10 \%$ reducing agent and $5 \mathrm{ml}$ of organic reagent solution. Then the solution was extracted by $10-15 \mathrm{ml}$ of chloroform and collected the aqueous layer as an iron-free buffer solution.

\section{Iron-free reducing agent solution}

The prepared reducing agent solution was also made iron-free by the similar process of extraction by using chloroform. The aqueous layer was collected for use as an iron-free reducing agent solution.

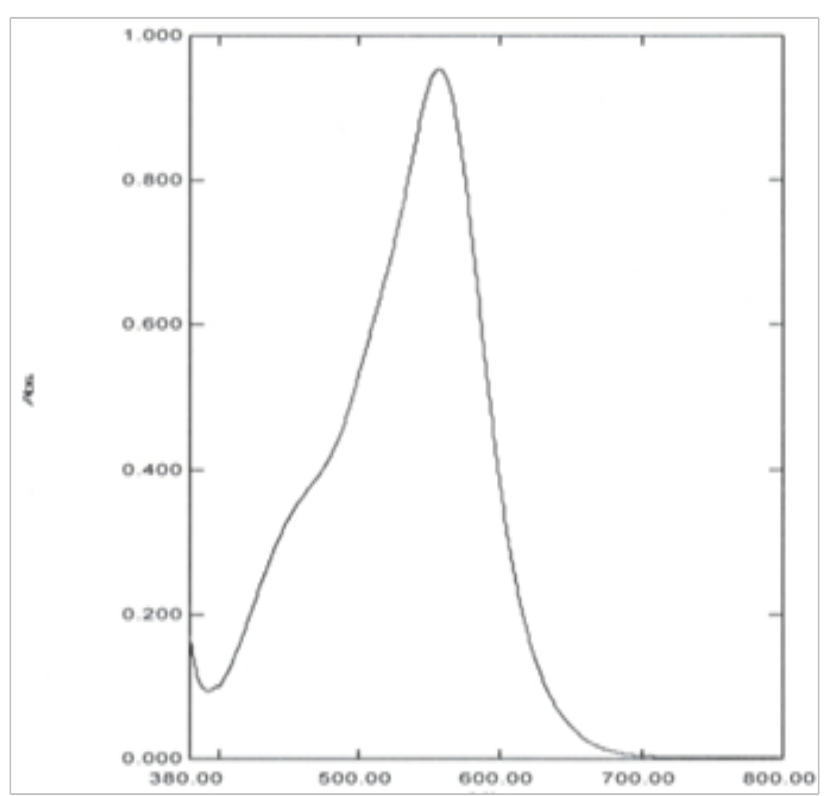

Apparatus

A double beam UV-Visible Spectrophotometer, (Model: UV/Vis-1800 SHIMADZU, Japan), a digital pH meter (Mi 151, pH/ORP/Temperature Bench Meter, U.S.A) were used in this research work.

\section{Samples collection and preservation}

\section{Water samples}

The water samples were collected from an arbitrary selecting of tube-wells from different areas of Jashore city and preserved in clean plastic bottles for experiments. The people mainly use this water for drinking purposes as well as household activities.

\section{Food samples}

Food samples (banana, spinach, date, nut) were collected from the local markets of Jashore. The samples were preserved in a suitable dry condition for further analysis.

\section{Pharmaceutical samples}

Medicinal iron-containing samples (tablets and capsules) of different companies were collected from the local pharmacies of Jashore, Bangladesh.

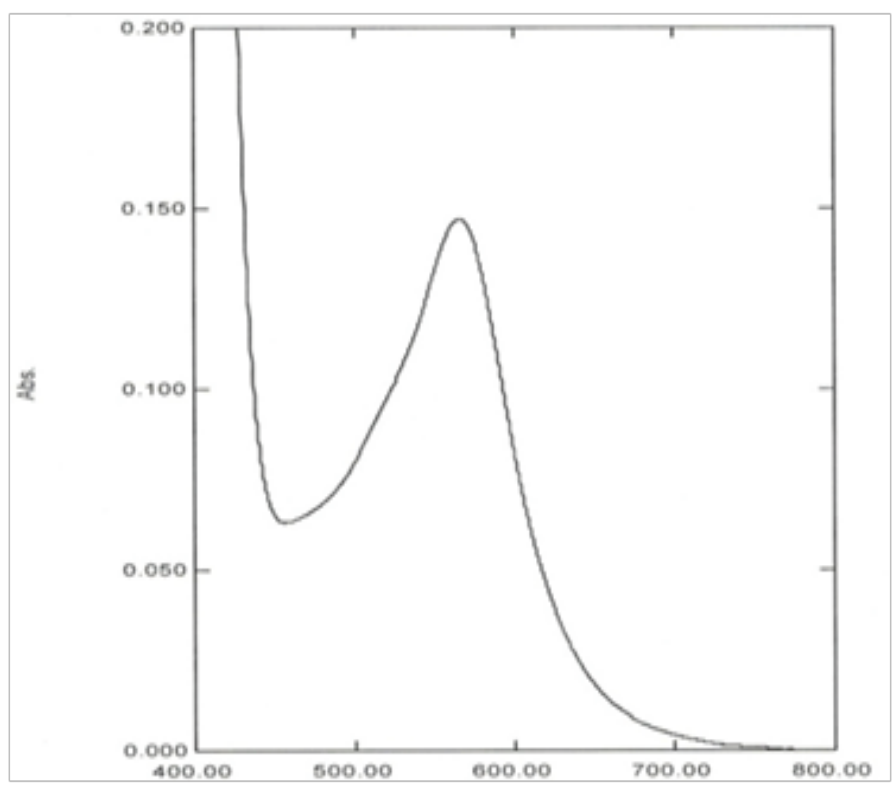

Fig. 1. Absorption spectrum of iron(II) complex of PDT (left side) and PBMPT (right side) in aqueous ethanol medium recorded against reagent blank. 
Table I. Absorption Characteristics of iron(II) complexes of PDT and PBMPT

\begin{tabular}{|c|c|c|c|c|c|}
\hline \multirow{3}{*}{$\begin{array}{l}\text { Organic } \\
\text { reagent }\end{array}$} & \multirow{3}{*}{$\begin{array}{l}\text { Color of } \\
\text { complex }\end{array}$} & \multicolumn{2}{|c|}{ Aqueous-ethanol medium } & \multicolumn{2}{|c|}{ Chloroform medium } \\
\hline & & $\lambda_{\max }(\mathrm{nm})$ & $\varepsilon$ & $\lambda_{\max }(\mathrm{nm})$ & $\varepsilon$ \\
\hline & & & $\left(\mathrm{L} \mathrm{mol}^{-1} \mathrm{~cm}^{-1}\right)$ & & $\left(\mathrm{L} \mathrm{mol}^{-1} \mathrm{~cm}^{-1}\right)$ \\
\hline PDT & Magenta & 556.0 & 24,026 & 556.0 & 24,153 \\
\hline PBMPT & Violet & 561.0 & 31,064 & 560.0 & 31,269 \\
\hline
\end{tabular}

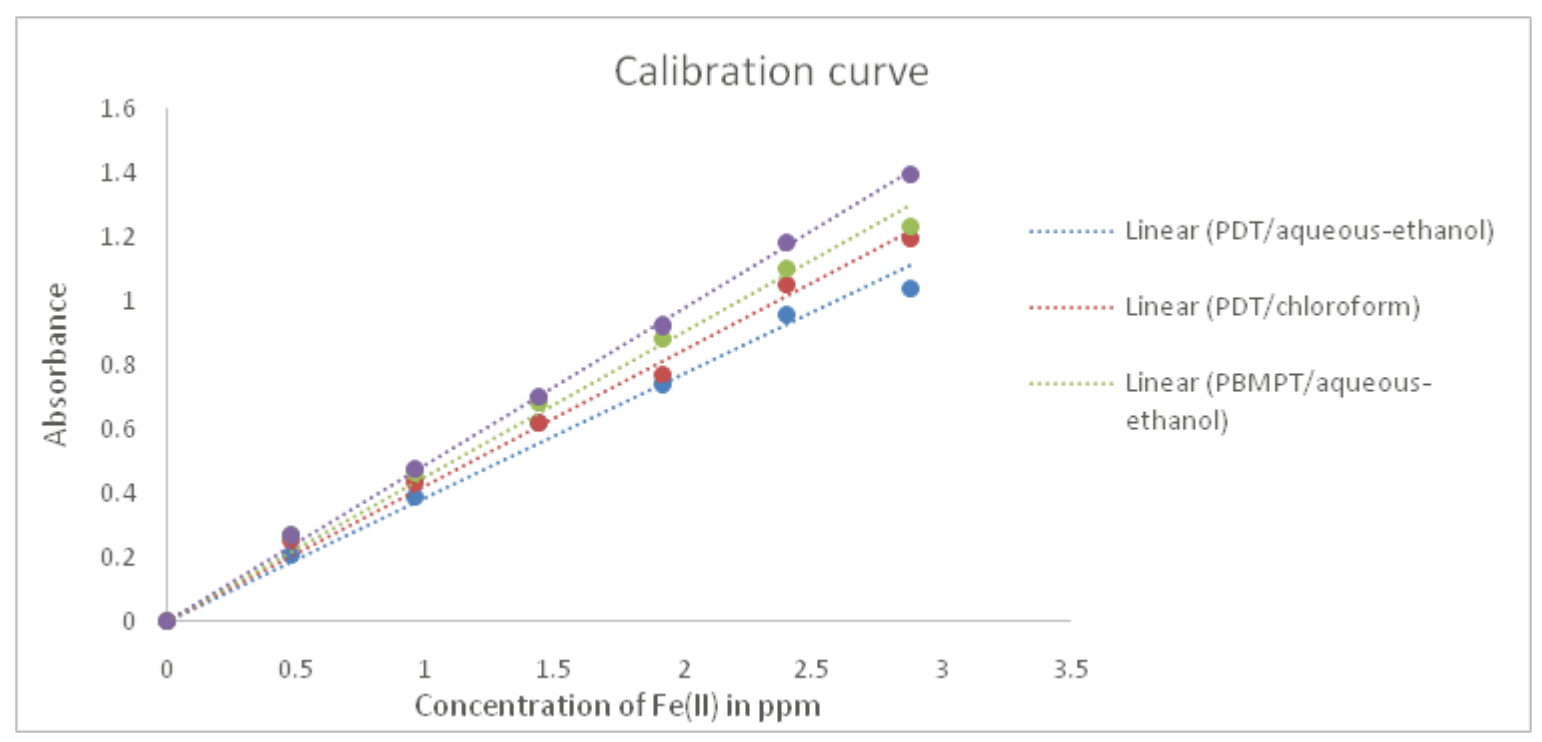

Fig. 2. Calibration of both PDT-iron(II) and PBMPT-iron(II) complexes in aqueous-ethanol as well as chloroform medium

\section{Analytical procedure}

General procedure of iron(II) complexes of organic reagents

The iron(II) complexes of PDT and PBMPT were prepared for spectrophotometric determination by the following general procedure: in a $25 \mathrm{ml}$ volumetric flask, $5.0 \mathrm{ml}$ of iron(II) solution, $2 \mathrm{ml}$ of $10 \%(\mathrm{w} / \mathrm{v})$ hydroxylamine hydrochloride, and $5 \mathrm{ml}$ of the organic reagent solutions were added followedby $5 \mathrm{ml}$ buffer solution of $\mathrm{pH} 4.76$. Then the contents were up to the mark by adding ethanol. Absorptions of all solutions were recorded against similarly prepared reagent blanks in the appropriate solvents. The wavelengths of maximum absorbance, $\left(\lambda_{\max }\right)$ of PDT iron(II) and PBMPT-iron(II) complexes were recorded. Specific absorptivity (a) and molar absorptivity ( $\varepsilon$ ) of different concentrations of iron(II) complexes at the wavelength of maximum absorbance calculated from the linear regression coefficient in terms of absorbance versus concentration were determined

\section{Preparation of water samples}

The collected water samples were extracted in chloroform medium followed by the general procedure of complex formation. The chloroform layers were collected into a $25 \mathrm{ml}$ calibrated flask and diluted to volume with chloroform.

\section{Preparation of pharmaceutical tablet samples}

Adequate amount (2.5 g) of the powdered tablet sample was taken in a $100 \mathrm{ml}$ beaker and $10 \mathrm{ml}$ of $2.0 \mathrm{M} \mathrm{HCl}$ was added with carefully stirring. The diluted mixture was filtered and collected in a $50 \mathrm{ml}$ volumetric flask making up to the mark with distilled water. The color of the iron(II) complex was developed using the following general recommended procedure. 


\section{Preparation of food samples}

The collected food samples were dried and turned into ash by heating in a porcelain crucible. The powdered samples were dissolved in $10 \mathrm{ml}$ of $2.0 \mathrm{M} \mathrm{HCl}$ with careful stirring. The mixture was diluted by adding $10 \mathrm{ml}$ of distilled water and collected in a $50 \mathrm{ml}$ volumetric flask followed by filtration. The color of the iron(II) complex was developed using the recommended procedure.

Determination of iron content from water, food, and pharmaceutical samples

The absorbance of the prepared solutions was measured at $\lambda_{\max }$ against the reagent blank and the iron content of the sampleswas calculated from the calibration curve. At least three to four separate determinations were carried out with each sample. Experimental validity was confirmed by repeated measuring the samples by the addition of a known amount of iron.

\section{Results and discussion}

The visible absorption spectrum of the iron(II) complexes of PDT and PBMPT in ethanol-aqueous medium showed a single sharp peak with a maximum absorbance at 556 and $561 \mathrm{~nm}$ respectively. The molar absorptivities of iron(II)

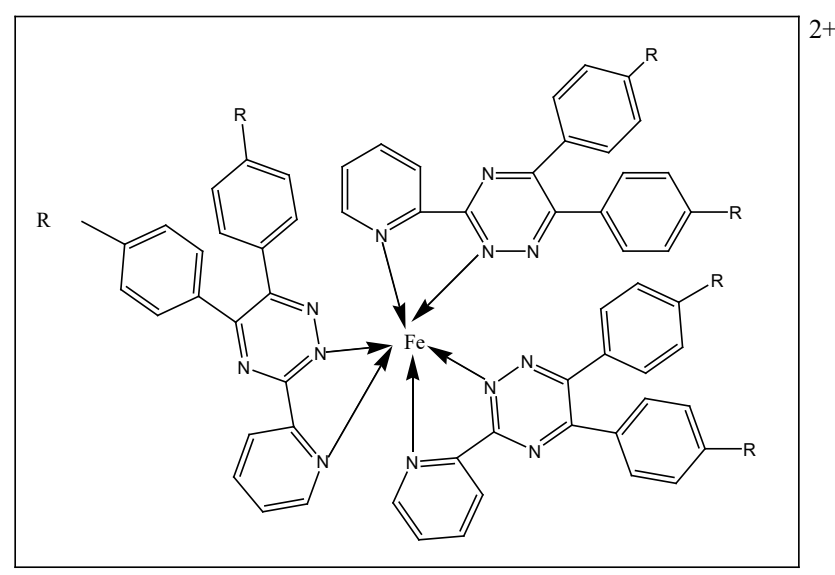

Fig. 3. Schematic representation of the complex $\left[\mathrm{FeL}_{3}\right]^{2+}$ (When $\mathrm{R}=\mathrm{H}, \mathrm{L}=\mathrm{PDT}$ and $\mathrm{R}=\mathrm{OCH}_{3}, \mathrm{~L}=\mathrm{PBMPT}$ )

complexes of PDT and PBMPT at $\lambda_{\max }$ in aqueous ethanol medium are 24,026 $\mathrm{Lcm}^{-1} \mathrm{~mol}^{-1}$ and $31,064 \mathrm{Lcm}^{-1} \mathrm{~mol}^{-1}$ respectively. The spectral characteristics found in this investigation i.e., $\lambda_{\max }$ and molar absorptivity $(\varepsilon)$ are almost
Table II. Iron content of pharmaceutical samples determined by PDT and PBMPT

\begin{tabular}{lcc}
\hline $\begin{array}{l}\text { Name of } \\
\text { iron tablets }\end{array}$ & \multicolumn{2}{c}{$\begin{array}{r}\text { Mean of iron found } \\
\end{array}$} \\
\cline { 2 - 3 } & PDT & PBMPT \\
\hline Ipec-plus & 262.79 & 330.3 \\
Itop-ct & 137.71 & 184.9 \\
Hemofix F2 & 202.35 & 255.1 \\
\hline
\end{tabular}

Table III. Iron content of water samples determined by PDT and PBMPT

\begin{tabular}{|c|c|c|}
\hline \multirow{2}{*}{$\begin{array}{c}\text { Depth } \\
\text { of tube } \\
\text { well (ft) }\end{array}$} & \multicolumn{2}{|c|}{$\begin{array}{l}\text { Mean of iron found } \\
\quad \times 10^{2} \mathrm{mg} \mathrm{L}^{-1}\end{array}$} \\
\hline & PDT & PBMPT \\
\hline 160 & 3.673 & 3.82 \\
\hline 170 & 1.7410 & 2.25 \\
\hline 175 & 2.660 & 2.79 \\
\hline 160 & 0.854 & 1.09 \\
\hline 170 & 0.255 & 0.29 \\
\hline 180 & 0.197 & 0.20 \\
\hline 160 & 0.950 & 1.15 \\
\hline 165 & 1.071 & 1.34 \\
\hline 140 & 2.174 & 2.89 \\
\hline 175 & 0.765 & 0.97 \\
\hline 75 & 1.173 & 1.49 \\
\hline 100 & 1.639 & 2.10 \\
\hline 145 & 0.216 & 0.33 \\
\hline 100 & 0.86 & 0.98 \\
\hline 630 & 1.156 & 1.26 \\
\hline 80 & 0.216 & 0.23 \\
\hline 100 & 0.425 & 0.51 \\
\hline 180 & 1.001 & 1.09 \\
\hline 120 & 0.29 & 0.38 \\
\hline 70 & 0.26 & 0.34 \\
\hline
\end{tabular}


like those of the reported values of Islam and Stephen (1993). The stoichiometry of the iron(II) complexes of as-triazines; PDT and PBMPT were determined by both the molar ratio method and the Job's continuous variation method. The results of this study are shown that these ligands PDT and

Table IV. Iron content of food samples determined by both PDT and PBMPT

\begin{tabular}{|c|c|c|}
\hline \multirow[t]{2}{*}{ Food samples } & \multicolumn{2}{|c|}{$\begin{array}{l}\text { Mean of iron found } \\
\quad \times 10^{2} \mathrm{mg} \mathrm{L}^{-1}\end{array}$} \\
\hline & PDT & PBMPT \\
\hline $\begin{array}{l}\text { Plantain } \\
\text { banana(green) }\end{array}$ & 0.156 & 0.212 \\
\hline $\begin{array}{l}\text { Cavendish } \\
\text { banana(yellow) }\end{array}$ & 0.239 & 0.395 \\
\hline $\begin{array}{l}\text { Cavendish } \\
\text { banana(green) }\end{array}$ & 0.177 & 0.309 \\
\hline $\begin{array}{l}\text { Blue-java } \\
\text { banana(yellow) }\end{array}$ & 0.840 & 0.797 \\
\hline $\begin{array}{l}\text { Manzano } \\
\text { banana(green) }\end{array}$ & 0.185 & 0.191 \\
\hline $\begin{array}{l}\text { Blue-java } \\
\text { banana(green) }\end{array}$ & 0.247 & 0.347 \\
\hline $\begin{array}{l}\text { Baby } \\
\text { banana(yellow) }\end{array}$ & 0.205 & 0.179 \\
\hline $\begin{array}{l}\text { Burro } \\
\text { banana(green) }\end{array}$ & 0.168 & 0.207 \\
\hline $\begin{array}{l}\text { Baby } \\
\text { banana(green) }\end{array}$ & 0.108 & 0.094 \\
\hline $\begin{array}{l}\text { Manzano } \\
\text { banana(yellow) }\end{array}$ & 0.224 & 0.231 \\
\hline $\begin{array}{l}\text { Plantain } \\
\text { panana(yellow) }\end{array}$ & 0.190 & 0.201 \\
\hline Spinach & 1.034 & 0.954 \\
\hline Peanut & 0.244 & 0.261 \\
\hline Date & 0.161 & 0.192 \\
\hline
\end{tabular}

PBMPT form tris-complexes with iron(II) acting as bidentate ligands.

\section{Determination of iron}

Determination of iron from water samples was carried out based on the extraction of iron(II) complexes of PDT and PBMPT in chloroform. In the case of foods and pharmaceutical samples, the prepared solutions were directly transferred to the cell from the $25 \mathrm{ml}$ volumetric flask for measuring the absorptions. Experimental samples were analyzed in multiple times using both PDT and PBMPT and the results are given in Table II-IV.

Quantitative recovery of iron was confirmed by the standard addition method. Multiple determinations of trace amount of iron in water samples, food samples (date, banana, peanut), and pharmaceutical tablets proved successful, yielding results with a very small standard deviation.

\section{Conclusion}

In this study, it is confirmed that as-triazine containing ferroin-yielding reagents are highly effective and convenient for determination of trace amount of iron from natural samples. The results found in this research mention that the amount of iron in water is within the acceptance limit by WHO. However, the people who have the symptoms of iron deficiency shouldinclude iron-rich food like dates, bananas, peanuts, and iron tablets in their daily diets by the consultation of doctors. On the other hand, those who have iron toxicity should avoid these foods. To have sound health, we should ingest foods providing a balanced amount of iron in our body.

\section{References}

Avissar YY, Sagiv AE, Mandler D and Almog J (2004), Identification of Firearms Holders by the [Fe(PDT)] complex. Quantitative determination of iron transfer to the hand and its dependence on palmar moisture levels, Journal of Forensic Sciences 49(6): 1215-1219. DOI: org/10.1520/ JFS2004100.

Bellam R and Jaganyi D (2017), Substitution Kinetics of [Fe(PDT/PPDT) (phen)] with 2,2'- Bipyridine, 1,10-Phenanthroline, and 2,2',6,2"-Terpyridine, International Journal of Chemical Kinetics 49(3): 182-196. DOI: org/10.1002/kin.21066. 
Bosscher D, Caillie-Bertrand MV, Robberecht H, Dyck KV, Cauwenbergh RV and Deelstra H (2001), In vitro availability of calcium, iron, and zinc from first-age infant formulae and human milk, $J$. Pediatr. Gastroenterol. Nutr. 32(1): 54-58. DOI: org/10.1097/00005176-200101000-00016.

Clara C (2015), Iron deficiency: new insights into diagnosis and treatment, Hematology Am Soc Hematol Educ Program 2015(1): 8-13. DOI: org/10.1182/ asheducation-2015.1.8.

Cronin SJF, Woolf CJ, Weiss G, and Penninger JM (2019), The role of iron regulation in immuno-metabolism and immune-related disease, Front. Mol. Biosci. 6: 116 . DOI: org/10.3389/fmolb.2019.00116.

Douglas JH, Gary RR, Frank ES and Stephen LT (1984), Ferene: A new spectrophotometric reagent for iron, Canadian Journal of Chemistry 62: 4 .

Furniss BS, Hannaford AJ, Smith PWG and Tatchell AR (1978), Vogel's text book of practical organic chemistry, $4^{\text {th }}$ Ed., pp 1043-1046.

Hedayati M, Sharif BA, Khattab M, Razavi A, Mohammed I, Nejad A, Wabler M, Zhou H, Mihalic J, Gruettner C, Weese TD and Ivkov R (2018), An optimized spectrophotometric assay for convenient and accurate quantification of intracellular iron from iron oxide nanoparticles, Int. J. Hyperth 34(4): 373-381. DOI: org/10.1080/02656736.2017.1354403.

Hossain MM, Islam MA, Begum $\mathrm{S}$ and Parvin $\mathrm{M}$ (2019), Determination of trace amount of iron with as-triazine containing ferroin-functional group, Dhaka Univ. J. Sci 67(2): 335-346.

Hoffman R (2013), Iron: deficiency and toxicity.

Islam MA and Stephen WI (1993), 3,5,6-Trisubstituted 1,2,4-triazines as analytical reagents Part I. Compounds containing the ferroin functional group or iron(II)-methine chromophore, Anal. Chem. Acta 274(2): 335-346. DOI: org/ 10.1016/0003- 2670(93)80483-2.
Islam MA and Stephen WI (1992), Evaluation of some astriazines and re-evaluation of PDT and ferrozine as reagents for spectrophotometric determination of ruthenium, Talanta 39(11): 1429-1435. DOI: org/10. 1016/00399140(92)80122-T.

Islam MA, Begum S, Parvin $\mathrm{M}$ and Hossain MM (2020), Determination of stability constants of iron(ii) complexes of as-triazines containing ferroin-yielding chromogens, Dhaka Univ. J. Sci. 68(2): 137-142.

Jenner GA, Longerich HP, Jackson SE and Fryer BJ (1990), ICP-MS: A powerful tool for high-precision trace-element analysis in Earth sciences, Evidence from analysis of selected USGS reference samples, Chem. Geol. 83: 133-148.

Kamal MM, Aly AAM, El-meligy MS and Elsaid AI (1989), Studies on some metal chelates of 8hydroxy-quinoline-5-sulphonylhydrazide, Synthesis and Reactivity in Inorganic and Metal-Organic Chemistry 19(6): 557-569. DOI: org/10.1080/ 00945718908048093.

NAP (National Academy Press) (2001), Dietary reference intakes for vitamin a, vitamin $\mathrm{k}$, arsenic, boron, chromium, copper, iodine, iron, manganese, molybdenum, nickel, silicon, vanadium, and zinc : a report of the panel on micronutrients, Washington DC.

Patil US, Adireddy S, Jaiswal A, Mandava S, Lee BR and Chrisey DB (2015), In vitro/in vivo toxicity evaluation and quantification of iron oxide nanoparticles, Int. J. Mol. Sci. 16(10): 24417-24450. DOI: org/10. 3390/ijms 161024417.

Riemer J, Hoepken HH, Czerwinska H, Robinson SR and Dringen R (2004), Colorimetric ferrozine-based assay for the quantification of iron in cultured cells, Anal. Biochem 331(2): 370-375. DOI: org/10.1016/ j.ab.2004.03.049. 
Slavin W (1988), Atomic absorption spectrometry, In methods in enzymology 158: 117-145. DOI: org/10. 1016/0076-6879(88)58052-7.

Viollier E, Inglett PW, Hunter K, Roychoudhury AN and Cappellen PV (2000), The ferrozine method revisited: $\mathrm{Fe}(\mathrm{II}) / \mathrm{Fe}(\mathrm{III})$ determination in natural waters, Appl. Geochem. 15: 785-790. DOI: org/10.1016/ S0883- 2927(99)00097-9. 